\title{
THE LEGALITY OF THE 2020 REGIONAL ELECTION ON STATE CONDITIONS IN A HEALTH EMERGENCY
} https://doi.org/10.47743/jopafl-2021-19-16

\author{
MARUADI \\ Faculty of Law, Lambung Mangkurat University, \\ Banjarmasin, Indonesia \\ maruadi.fh@outlook.com \\ M. Hadin MUHJAD \\ Faculty Law, Lambung Mangkurat University, \\ Banjarmasin, Indonesia
}

\begin{abstract}
The legal basis for organizing regional elections (Pilkada) during this pandemic is Law no. 6 of 2020 which is the amendment of Law no. 10 of 2016. The amendments contained in Article 122, Article 201 and Article 202 are only about postponing the implementation of the 2020 Pilkada simultaneously, but there is no regulating the implementation of the Pilkada during the pandemic period. The 2020 simultaneous regional elections will be held on December 9 2020, this means that all stages of the elections are still in a pandemic period because the President has not revoked the health emergency stipulation based on Presidential Decree No. 11 of 2020. Meanwhile, derivative regulations such as PKPU No.5 of 2020 does regulate several restrictions in response to the implementation of the regional elections during the pandemic. Thus the simultaneous regional elections 2020 which were held during the pandemic which did not have the basis for the Law on the Pilkada during the pandemic, clearly have the potential to cause the implementation of the regional elections to be invalid because there is no legal basis.
\end{abstract}

Keywords: regional election, pandemic, regulation.

\section{Introduction}

The implementation of the 2020 regional elections has experienced a delay from the original schedule set by the KPU. Officially the postponement of the 2020 regional elections is outlined in Government Regulation in Lieu of Law (Perppu) Number 2 of 2020 concerning the Third Amendment to Law Number 1 of 2015 concerning Stipulation of Government Regulations in Lieu of Law Number 1 of 2014 concerning Election of Governors, Regents, and the mayor, which was later enacted as Law no. 6 of 2020 concerning Stipulation of Government Regulation in Lieu of Law (Perppu) Number 2 of 2020 concerning the Third Amendment to Law Number 1 of 2015 concerning Stipulation of Government Regulations in Lieu of Law Number 1 of 2014 concerning Election of Governors, Regents and Mayors. The postponement of the 2020 simultaneous regional elections is because our nation is being hit by a pandemic and our country has declared a health emergency based on Presidential Decree No.11 of 2020 concerning the Determination of Public Health Emergencies for Corona Virus Disease 2019 (COVID-19), published on March 31, 2020. 
The provisions for the simultaneous postponement of the 2020 regional elections are contained in the Amendment to Article 120 and the addition of Articles 122A and 201A, in full as follows:

- Amendment to Article 120 paragraph (1) which reads as,

"In the event that in part of the Electoral area, the entire Electoral area, the majority of the region, or the entire area, riots, security disturbances, natural disasters, non-natural disasters, or other disturbances occur which result in part of the Election or simultaneous Election implementation stages not being implemented, a further Election shall be carried out or Continuous selection continued"'.

'The continued election or continuous selection as referred to in paragraph (1) starts from the stage of holding the Election or the simultaneous Election which has stopped.,'”

Between Article 122 and Article 123 is inserted 1 (one) article, for Article 122A which in Article 122A paragraph (1) reads,

'The continued simultaneous election as referred to in Article 120 is carried out after the determination of the postponement of the simultaneous Election stage with the General Election Commissions (KPU) Decree is issued'’.

According to Article 122 A paragraph (2), the determination of the postponement of the simultaneous Election implementation stages as well as the continued simultaneous Election as referred to in paragraph (1) shall be carried out with the mutual consent of the KPU, the Government and the House of Representatives. " Further provisions regarding the procedure and time for the implementation of further simultaneous Elections are regulated in KPU Regulations (Article 122 A paragraph (3).

Furthermore, between Article 201 and Article 202 is inserted 1 (one) article, for Article 201A paragraph (1) which reads:

- $\quad$ Simultaneous voting as referred to in Article 201 paragraph (6) is postponed due to a non-natural disaster as referred to in Article 120 paragraph (1).

(2) The postponed simultaneous voting as referred to in paragraph (1) shall be held in December 2020. (Provisions for Article 122 paragraph (2).

In the event that simultaneous voting as referred to in paragraph (2) cannot be implemented, according to Article 122 paragraph (2), simultaneous voting is postponed and rescheduled immediately after the non-natural disaster as referred to in paragraph (1) ends, through the mechanism referred to in Article 122A.

The provisions of Article 122 and Article 201, Article 202 of the Election Law as the postponement article above are intended to be due to the Corona Virus Disease 2019 (“COVID-19”) pandemic which has basically been designated by the President as a type of disease that causes a public health emergency. Although the articles of the Pilkada Law do not regulate the implementation of pilkada in a pandemic condition.

In fact, if we look closely at the provisions of Article 122 of the Pilkada Law, it is intended not to postpone the meaning of the entire territory of Indonesia but for regions per region or tps per tps so that the provisions are referred to in Chapter XVI for Advanced Elections and Secondary Elections, while the reasons for postponement after amendments are added with the sentence disaster. non natural. Thus the provisions for postponement based on Article 122 are not intended to be due to a pandemic, because if the provisions for postponement are due to a pandemic, many articles in the Pilkada Law will follow the conditions in accordance with the health emergency. 
Based on the background of the problems above, the problem can be formulated whether it is legal to hold regional elections during a pandemic based on the Pilkada Law which does not regulate Pilkada in a pandemic or the Pilkada Law only regulates normal conditions?

\section{Results and discussion}

The state of the abnormality of our country due to the outbreak of the Covid-19 disease is based on Presidential Decree No. 11 of 2020 as a health emergency, and this can also be seen in KPU Decree No. 179 / PL.02- Kpt / 01 / KPU / III / 2020 concerning the Postponement of the Stages of Election for Governors and Deputy Governors, Regents and Deputy Regents, and / or Mayor and Deputy Mayors in 2020. The decree broadly consists of 4 stages of holding postponed regional head elections including the inauguration of voting committees, verification of support requirements for individual candidates. , the establishment of Voter Data Updating Committee, as well as updating and compiling voter lists. Referring to the current situation due to the Covid-19 pandemic outbreak, the advanced selection mechanism is more appropriate to be implemented and set as an option. However, what becomes an obstacle for the choice of further election only refers to each respective region. However, it becomes a dilemma that the Pilkada Law does not regulate with regard to dangerous situations nationally, so it must be postponed simultaneously due to the widespread spread of this epidemic and for the sake of maintaining the health of the people. However, as a greater risk disaster mitigation effort, it needs to be appreciated when the KPU issued a step to postpone the 4 stages of the 2020 Pilkada as the right and responsive step in addressing the current situation to suppress the spread of the Covid-19 pandemic that is increasingly widespread.

Seeing the condition of the pandemic, all stages of regional head elections should be postponed totally. In terms of starting the postponed election stages based on KPU Decree Number 179 / PL.02-Kpt / 01 / KPU / III / 2020, including the postponement of the following stages to the voting stage, because it is impossible to hold elections according to the agenda set out in the law. -invited, if the covid-19 pandemic has not been completely finished. Indeed, the State should first focus on basic and fundamental matters, namely efforts to deal with the Covid-19 pandemic outbreak that has attacked Indonesia and strive for the welfare of its people equally.

As we know, the pilkada, which is carried out directly by the people, is one of the main means of realizing people's sovereignty in order to produce a democratic state government. The 1945 Constitution has clearly emphasized that general elections are held by a general election commission that is national, permanent and independent (Article 22E Paragraph (5) of the 1945 Constitution) which is based on elections: direct, general, free, secret, honest and fair (Article 22E paragraph (1) of the 1945 Constitution). It is realized that carrying out elections during the Covid 19 pandemic is very tough, difficult and expensive. So the Government must ensure safety, especially strict health procedures in elections. Among other things, the carrying capacity of the election is a legal framework that provides security protection in implementing election techniques. That the realization of free and fair elections must be made within a framework that ensures transparency in the electoral process. Fair for the electorate as well as for the organizers. There are no worries and shadows of fear for the organizers in carrying out the stages in the midst of the Covid 19 pandemic (Raden, 2020). 
It takes a solid electoral framework, namely in the form of a legal framework that can ensure that election organizers have integrity, have strong capabilities and capacities. Culturally, it is also expected that there will be a conducive political nature that has the carrying capacity of participants, organizers and voters both in the election process and results. In addition, it ensures high voter participation so that there is legitimacy for the elected regional head.

Many experts have agreed to state that elections are one of the important pillars in a democratic country. In short, a country will not be called democratic if the head of government and the people's representatives who sit in parliament are not elected through an election process. Elections are said to be democratic when they are carried out in a manner "free and fair election". It is stated emphatically that "free and fair elections are essential in assuring the consent of the governed" (Democracy in Brief, Bureau of Information Program US Departments of State). A democratic system based on law and people's sovereignty is the basis of life in the nation and state. Democracy as a system of government adopted by Indonesia states that a government is led by the people, by the people, and for the people. The embodiment of the democratic system is the holding of direct elections. The basic basis for the implementation of elections is article $22 \mathrm{E}$ paragraph (1) of the 1945 Constitution which has mandated the holding of quality elections, including the widest possible participation of the people on the principles of democracy, namely direct, general, free, secret, honest and fair through a law. invitation.9 General elections or Pilkada as a means of exercising people's sovereignty which is carried out directly, publicly, freely, honestly and fairly by guaranteeing the principles of representation, accountability and legitimacy in the Unitary State of the Republic of Indonesia based on Pancasila and the 1945 Constitution.

The problems are not simple but they are so complex, including the ideas and concepts of the Indonesian rule of law that are so complex and complicated, even though it is known that many legal problems have not been properly resolved, especially in matters of the legal system and legal instruments in realizing legal certainty. Because apart from that there are not many choices for this pluralistic nation if it wants to survive, except to create a rule of law. Thus the essence (essence) of democracy lies in the real role of the people in the political process that runs especially in the making and implementation of public policies, namely various programs aimed at solving various public problems (society, nation and state) which are decided by the authorized official or institution. Public problems, for example: developing freedom of expression, overcoming poverty and unemployment, increasing the right of citizens to obtain education and health services and so on.

In a constitutional constitutional state, the state in implementing the postponement of the elections is in accordance with the provisions of the constitution, namely in the form of statutory regulations as a constitutional guarantee for the postponement of the 2020 Pilkada. able to protect the people and guarantee welfare (Preamble to the 1945 Constitution). In accordance with the adage put forward by Cicero in his book De Legibus which reads "Salus populi suprema lex esto". This means that people's safety is the highest law (Asshiddique, 2010). If you look at the context of the precarious situation, coercion and the inability of the Pilkada Law to respond to the current situation, a policy in the form of a Government Regulation in Lieu of a Law is the right thing. This is based on Article 22 
of the 1945 Constitution that "In the event of a compelling crisis, the President has the right to stipulate government regulations as a substitute for the Law."

The Perppu Pilkada can be used as legality for the postponement of simultaneous regional elections for 2020. In the material content of the Perppu, it must include at least several things including the status of post-postponement stages, the scheme for filling regional head positions for regions that experience regional head vacancies before the implementation of the pilkada, the 2020 election budget reallocation mechanism and determining the source of the post-postponement pilkada budget and at least paying attention to the implementation of the election with the design of the electoral arrangement which is specifically contained in the Constitutional Court Decision Number 55 / PUUXVII / 2019 concerning the constitutionality of the simultaneous election model so that there is no patchwork in determining the schedule of the elections in the future. So if the state is responsive in responding to the postponement of regional elections through a Government Regulation in Lieu of a Law with all legal considerations and various other fields of study. So the law can run as a function according to Mochtar Kusumaatmadja (2002) that "Law should be used as a means to solve problems in the administration of the State.

The big question that arises is why the government together with the House of Representatives (DPR) and election organizers decide to continue implementing the 2020 regional elections in the midst of a pandemic? to answer this question, the KPU as the election organizer explained that the basis for making this decision referred to two things, namely Government Regulation in Lieu of Law (Perppu) Number 2 of 2020 concerning Pilkada and a letter of recommendation from the Task Force for the Acceleration of Handling Covid-19. In the Perppu signed by President Joko Widodo on May 4, 2020, Article 201A states that the simultaneous voting stages that were delayed due to nonnatural disasters, in this case the Covid-19 pandemic, will be held again in December 2020. Following up on that, the government, The DPR and the KPU then decided on the day for the 2020 regional elections to fall on December 9. This decision was taken after consultation with all stakeholders, including the Task Force for the Acceleration of Handling Covid-19, the Ministry of Health (Kemenkes), and experts. Although, the same article also states that there is an option that allows for the postponement of the simultaneous regional election stages again until the situation and conditions support for the implementation of voting. Then the second basis is a letter of recommendation from the Task Force for the Acceleration of Handling Covid-19. Doni Munardo, as Chair of the Task Force for the Acceleration of Handling Covid-19, has given the green light to resume the 2020 simultaneous regional elections.

There is only one condition stipulated, namely that its implementation must comply with and carry out the Covid-19 health protocol. The reason is, based on data from the Task Force for the Acceleration of Handling Covid-19, of the 261 districts / cities that will carry out the elections, 40 of them are at high risk or the red zone for the spread of the corona virus. Meanwhile, as many as 99 districts / cities are in the orange zone or moderate risk, 72 districts / cities are in the yellow zone or low risk, and 43 districts / cities are in the green zone or are not affected by the spread of Covid-19. However, this is temporary data and is dynamic in nature. It could be that areas that enter the red zone ahead of the Pilkada turn into a yellow zone, or vice versa, the yellow zone can become an orange zone, even a red zone. Therefore, the health protocol must be carried out in all stages of the election and 
election organizers must be able to know in detail and follow the latest developments in which areas are green, yellow, orange, and red zones. In addition to Perppu No.2 of 2020 and the recommendation letter of the Task Force for the Acceleration of Handling Covid19, the KPU also mentioned a number of other reasons why the regional elections should be held in the midst of a pandemic. First, until now no single person or institution can confirm when the Covid-19 pandemic will end. The World Health Organization (WHO) itself some time ago gave the view that Covid-19 will not disappear automatically even once a vaccine has been found. In fact, they predict this virus will not disappear and will continue to exist side by side with humans (Rohim, 2016).

The next reason is, as was mentioned earlier, that currently all activities in various sectors have been allowed to gradually return in preparation for an era of adaptation to new habits. When the pilkada stages are not continued, this will be contradicting the government's policy. On the one hand, they allowed the public to return to their activities, but on the other hand, the elections were not continued. This will certainly be another question for the community.

Lastly, the KPU's consideration concerns election funds. If the pilkada is postponed again and passes the current year or is held in 2021, then the budget that has been disbursed this year will be wasted because it has passed the year of use. Meanwhile, the funds that have been disbursed have reached Rp. 4.1 trillion.

The government's argument that proposes the election for the election to be held in December 2020 has generated a lot of debate. Among them, as mentioned above, the Government argued about the takeover of the position of the regional head by the temporary acting and the reasons for not being explained when the corona pandemic ended, no party could confirm so that it was an excuse to implement it. Seeing the increasing trend of the spread of the corona virus actually suggests that the government is in a hurry to make decisions, without considering the conditions of society and not even seeing the political effects behind it. The fluctuation in the number of people exposed to Covid-19 along with the potential for very fast transmission through various mediums indicate that the social situation will not be the same.

The reason for the availability of officials is logical because it will be difficult to find officials at the intermediate and primary levels, especially since these positions are currently busy handling the outbreak, plus their limited authority later. The government's reason for referring to the Covid-19 emergency response period which ended on May 29, 2020 is considered less strong because it is only based on predictions that are inversely proportional to reality. The consideration of postponing the regional election to its sustainability must be based on the latest facts of the number of people exposed, then the number of people who have recovered to the mapping of areas prone to Covid-19. Not only partially guessing the development of certain regions, but the condition of all regions must also be seen nationally.

The handling of a pandemic in each region must be recognized differently depending on the implementation of the red zone. This means that attention should not only be focused on reducing the number of positive patients in a number of areas, but also on seeing preventive action and progress in areas where the number of patients is minimal. Because many areas have just started to become infected and the potential for spreading is increasingly widespread. So that the options taken really prioritize the safety of the entire community. At the same time, the discussion of the perppu to postpone the regional 
elections should not escape the attention of all parties. Legal certainty for postponing the elections should be hastened in order to avoid a legal vacuum because the mandate of the Election Law has not been implemented. With the Perppu, election organizers both KPU and Bawaslu can determine technical steps to formulate further regulations on the implementation of stages and their supervision. Although this epidemic has caused confusion in the implementation of the elections, as much as possible the legal basis must be prioritized. As stated by the Head of Bawaslu Abhan, certainty is part of the principle of elections. So that legal certainty and certainty of stages are the main points in the Perppu.

The vote for the simultaneous regional elections in 2020 has been decided on December 9, 2020, this means that the Pilkada stages have started to run again. The General Election Commission (KPU) has now restarted the stages that had been halted due to the Covid-19 pandemic. One of them is the matching stage and research (verification) of voter data. In the midst of the COVID-19 pandemic which has yet to subside, public concerns arise, can this Pilkada be held safely, safely and legally? Pilkada certainly does not only channel people's political participation, but also produces quality leaders. But how can this be done, if the situation is not as normal as it is today? The KPU has indeed published PKPU No.5 of 2020 concerning the stages, programs and schedule of the Pilkada. Thus, the KPU resumed its Pilkada activities which had been delayed some time ago due to the COVID-19 pandemic. One of the most crucial stages that is being and will be completed is factual verification of the support of individual candidates participating in the Pilkada. PKPU No. 5 of 2020, the stages of the regional elections have indeed adjusted to the pandemic conditions, but PKPU No. 5 of 2020, of course, based on the Pilkada Law which still regulates it in normal conditions.

As is well known, factual verification must be carried out for all individuals who provide support to prospective regional head candidates through individual channels. In this stage, KPU officers who will verify the terms of support for these candidates will directly visit individuals to prove the validity of the support they provide to the prospective regional head candidates. In this condition, the Regional KPU must equip its officers with Personal Protective Equipment (PPE) so that they are safe and secure in carrying out their duties so that they are not infected with the SARS-Cov-2 virus. Unfortunately, with the very kasip conditions and the limited availability of PPE, of course this will be a serious problem that will be faced by the KPU and Bawaslu in the early stages of PKPU implementation (Arinanto, 2000).

Indeed, many people think that the Pilkada during the COVID-19 Pandemic feels too forced. In fact, the readiness of the organizers seems very minimal. Not to mention the issue of the budget for activities that have been determined, not all regions can use it because not all regions experience budget difficulties due to overcoming COVID-19. With the necessity to follow health protocols in the implementation of this Pilkada, it is inevitable that the budget for providing PPE must be allocated to ensure that all stages, programs and schedules that have been determined can be implemented.

Indeed, there are a number of concerns about the holding of this Pilkada so that it may neglect the quality of the Pilkada administration. First, due to unsafe and healthy conditions, during the implementation of the Pilkada stages and programs, what emerged was a permissive attitude and ignoring violations of existing rules by field officers. Because it is human nature that tends to choose safe and secure at work, if they are in danger, such as being infected with the SARS-COV-2 virus. 
As a result, what has become their standard of work is neglected. This complaint actually appeared when the verification stage carried out on the support of the candidate for governor from the individual route carried out by KPU field officers was not implemented. Obviously this is detrimental to the verified individual candidate. Not to mention the other problems that will be faced when carrying out the next stages. Therefore, KPU professionalism is demanded so that public trust in the organizers of this Pilkada is maintained. This condition is what is actually feared, when the organizer is very permissive and ignores how the implementation of the rules that have been set. One of the impacts is of course on the quality of the Pilkada produced. This condition is indeed a very dilemma for the organizers (Asshiddique, 2012).

The bad experiences of the 2019 simultaneous elections still overshadow the organizers of this Pilkada, especially with the presence of KPPS officers who died during the simultaneous Election. Not meant to scare. Simultaneous elections in normal circumstances are already high pressure faced by the organizers. Moreover, the Pilkada which is held is under the risk of being infected with COVID-19. If this does not get serious attention, the polling stations that are visited by the public as voters will become a new cluster of COVID-19 transmission. This condition must be anticipated by the KPU and Bawaslu as Pilkada organizers. Second, the question arises, what if the state of the COVID19 pandemic gets worse, has the KPU prepared a backup plan to deal with this situation? For example, postponing the Pilkada in that area or canceling the overall implementation of the Pilkada or continuing to be carried out with the risk of being infected with COVID19. Until now, the KPU has not yet explained the reserve plan, because this is clearly more important so that there will be no chaos in the implementation of the Pilkada during this pandemic. The third problem that must also be of concern to the KPU and Bawaslu in the regions is the level of voter turnout in the Pilkada. In the condition that the spread of the SARS-COV-2 virus has not subsided, of course there are public concerns to follow every stage of the Pilkada. The chances of being infected by these voters are greater, especially on election day with the potential for large crowds to gather. This concern is what makes them prefer not to come to the polling stations on election day, if there is no guarantee of their safety.

The presence of these voters also correlates with the economic problems of the people affected by the COVID-19 pandemic. Not a few of those who work in the informal sector feel the impact of COVID-19 on their lives. The prediction figure from Bappenas will add around 5.23 million new unemployed and 5.71 million poor people in Indonesia. In fact, it is estimated that for the next year, those who are directly affected by COVID-19 will still have difficulty meeting their economic needs. If this group is faced with the choice of whether they have to go to work to make ends meet or have to come to a polling station, of course the realistic choice is to work. In order to reduce the weight of pressure on Pilkada organizers to run safe, healthy and with quality, of course all parties must play a role in helping the implementation of this Pilkada. The problem now is how these parties take part in the success of the Pilkada in conditions that are indeed "abnormal".

The first stages that took place after the agreement in the RDP were the stages of starting the PPK and PPS working periods which were carried out due to delays in the stages before the widespread pandemic, namely starting on June 15, 2020, formation of PPDP since June 19, 2020, and factual verification for 14 days since PPS has received support documents for individual candidates since June 24, 2020. At least from the author's 
observations, these are the three closest steps that election organizers will take for this year's regional elections. Thus, it needs to be realized that even though the election day is still December 9, in terms of preparation for the voting day, the implementation will be carried out within a few days after the hearing which decided that the Pilkada should be held during this pandemic.

Law Number 6 of 2020 has indeed been born and has been passed as law as an amendment to the previous Pilkada Law. However, due to the nature of amendments to the law, several clauses in the Pilkada Law apply unless there is an amended article regulated in Law Number 6 of 2020. Some of them are related to the provisions on the implementation of stages that are regulated and are still in effect stated in the law as referred to referred to in the elucidation of Article 20, namely verification of support from an individual candidate who is the task of PPS, is a research activity regarding the validity of a statement of support, a photocopy of an Electronic Identity Card, proof of the absence of multiple support, the absence of supporters who have passed away, the absence of supporters who are not again being a resident of the area concerned, or there are no supporters who do not have the right to vote. Furthermore, it is conveyed that the recapitulation of support for individual candidates is by making details on the names of individual candidate supporters based on the results of the verification signed by the chairman and members of PPS and known by the head of the sub-district / village head or other designations.

Because this clause has not changed, its technical implementation in the field must run in accordance with the statutory provisions. In accordance with the clause above, the managerial management of the stages carried out certainly requires a lot of interaction between organizers, voters and other stakeholders. Article 48 of the Pilkada Law even states that technically the implementation is carried out by the census method, namely by meeting directly with each candidate's supporters. If a candidate's supporters cannot be found during factual verification, the pair of candidates are given the opportunity to present their supporters at the PPS office no later than three days after the PPS cannot meet those supporters. This is an inherent concern because the implementation of these activities should start on June 24, 2020, and must be done face-to-face between the organizers and voters and other stakeholders. On the other hand, in the concluding clause of the hearing, it was stated that one of the requirements that must be done is that it must be in accordance with the health protocol in coordination with the Covid-19 Task Force and be guided by democratic principles. This of course will experience several obstacles, both juridical, technical, and budgeting in terms of implementation in the field.

The availability of derivative regulations as technical guidelines that must be available according to the Covid-19 protocol for each stage, namely the procurement of appropriate equipment availability and there is also an upstream downstream cycle of procurement to distribution, certainty of budgeting, as well as adequate socialization and technical guidance to officers and the public. In relation to the provision of the availability of derivative regulations as stipulated in the KPU Regulations, it is stated that the preparation and stipulation procedures require a long flow of time because a public examination must be carried out first. Furthermore, consultations with the House of Representatives and the government in a forum for hearings through the process of invitations at Kemenkumham This procedure takes a long time. 
Likewise with the following stages, such as checking the voter list until the final voter list is established in the regional elections, adequate forms of socialization and technical guidance, logistics procurement, polling station regression procedures to limit crowds, financing stages that must be adjusted to the current conditions of the Covid-19 pandemic in each region election. The standardization of its implementation is important in maintaining the safety of the people to improve public confidence in the credibility of election administrators as well as the quality of its implementation.

On the one hand, we continue to carry out the local democratization process through regional elections according to the provisions, but what is also very important is making all efforts to maintain the safety of all parties amid the Covid-19 pandemic. The readiness of all parties, starting from the acceleration of technical regulations, innovations that adapt to applicable regulations, including strict voter discipline are the main things so that the objective of implementing a democratic election with the hope of high legitimacy for the results can occur and still cares about safety in the face of this Covid-19 pandemic. Likewise, the sociological condition of the voting community has become a concern and even a consideration of the implementation of policy planning with the full support of all parties. budgeting, as well as adequate socialization and technical guidance to officers and the public.

In relation to the provision of the availability of derivative regulations as stipulated in the KPU Regulations, it is stated that the preparation and stipulation procedures require a long flow of time because a public examination must be carried out first. Furthermore, consultations with the House of Representatives and the government in a forum for hearings through the process of invitations at Ministry of Law and Human Rights (Kemenkumham). This procedure takes a long time.

Likewise with the following stages, such as checking the voter list until the final voter list is established in the regional elections, adequate forms of socialization and technical guidance, logistics procurement, polling station regression procedures to limit crowds, financing stages that must be adjusted to the current conditions of the Covid-19 pandemic in each region election. The standardization of its implementation is important in maintaining the safety of the people to improve public confidence in the credibility of election administrators as well as the quality of its implementation.

On the one hand, we continue to carry out the local democratization process through regional elections according to the provisions, but what is also very important is making all efforts to maintain the safety of all parties amid the Covid-19 pandemic. The readiness of all parties, starting from the acceleration of technical regulations, innovations that adapt to applicable regulations, including strict voter discipline are the main things so that the objective of implementing a democratic election with the hope of high legitimacy for the results can occur and still cares about safety in the face of this Covid-19 pandemic. Likewise, the sociological condition of the voting community has become a concern and even a consideration of the implementation of policy planning with the full support of all parties.

Holding elections in the midst of a public health crisis has become a decision taken by policy makers, but large, targeted and immediate planning through technical provisions is a necessity to avoid worsening the situation of the Covid-19 pandemic in the community. As is well known, Law no. 6 of 2020 concerning Postponement of Pilkada is the legal basis for postponing the implementation of regional head elections simultaneously from 23 
September 2020 to 9 December 2020. But more than that, the Perpu Pilkada also adjusts the rules of the game regarding further elections and subsequent elections, which become the basis for the implementation of regional elections in Indonesia. during the outbreak.

Article 120 of Law no. 6 of 2020 concerning Postponement of Pilkada regulates that:

In the event that in part of the Electoral area, the entire Electoral area, the majority of the region, or the entire area, riots, security disturbances, natural disasters, non-natural disasters, or other disturbances occur which result in part of the Election or simultaneous Election implementation stages not being implemented, a further Election shall be carried out or Continuous selection continued.

The implementation of the continued Election or the continued simultaneous Election as referred to in paragraph (1) starts from the stage of holding the Election or the simultaneous Election which is stopped. Article 120 of the Perpu Pilkada only adds one phrase from Article 120 which was regulated in the previous provision, namely 'nonnatural disaster'. However, this addition is essential because the COVID-19 pandemic has been declared a non-natural disaster, based on Presidential Decree No.12 of 2020 concerning the Determination of Non-Natural Disaster for the Spread of Corona Virus Disease 2019 (COVID-19) as a National Disaster. Based on this provision, it is regulated that the simultaneous voting for the Governor and Deputy Governor, the Regent and Deputy Regent, as well as the Mayor and Deputy Mayor of the 2015 election results which was originally held in September 2020, is postponed due to a non-natural disaster. Seeing the current conditions for the prevention of COVID-19, or at least until the Perpu Pilkada is issued on May 4, 2020, in my opinion it is very inappropriate to carry out the Pilkada. Based on existing data, the number of sufferers and deaths due to COVID-19 is still very high. The government still receives a lot of criticism due to delays in action and confusion of information and coordination in the field, so that many health protocols are not implemented by the community. Meanwhile, the actual implementation of the Pilkada in December 2020 as stipulated in the Perpu Pilkada, is only a matter of voting day.

Pilkada preparation, starting from candidate registration, verification, to campaigning, has been taking place since mid-June 2020. In fact, in June 2020, COVID19 data still showed a very high number. If the implementation is carried out since June, it is feared that this data will continue to rise, not sloping as expected and has happened in many other countries. On the other hand, there are financial problems too. Indonesia's economic condition is currently in decline, while strict health protocols have actually created an increase in the cost of implementing the Pilkada. Starting from sanitation equipment, masks, to waiting and voting facilitation which must be modified so that there is sufficient distance for voters. Pilkada actually does not need to be forced to be held in 2020. One of the reasons for the urgency of the Pilkada contained in the Perpu Pilkada is to maintain domestic political stability. Although it is not explained further in the Perpu Pilkada, in my opinion, there are concerns because there is an expired term of office, while the 2020 Pilkada is one of the Pilkada held simultaneously. Regarding this matter, actually Perpu No. 1 of 2014 and its amendments have regulated the existence of an executor of duties for regional heads whose term of office has expired.

To fill the vacant position of Governor, an acting Governor is appointed from an intermediate high leadership position up to the Governor's inauguration in accordance with the provisions of laws and regulations. Meanwhile, to fill the vacant position of Regent / 
Mayor, an acting Regent / Mayor is appointed from a high-ranking executive position up to the inauguration of the Regent and Mayor. Changing the Pilkada to be simultaneous does have a logical consequence of having a regional head whose term of office expires until the next simultaneous Pilkada. Thus, there is no legal problem here. What exists is a contestation of political interests in the regions. In fact, the lives of residents will be at stake.

In terms of juridically between the health emergency and the implementation of the Pilkada, several legal problems emerged, as stated by the Association for Elections and Democracy (Perludem) which encouraged the 2020 Pilkada to be postponed until 2021 so that the preparation time for the further election stages would be longer. Perludem Program Manager, Fadli Ramadhanil said, organizing regional elections in the midst of the Covid19 pandemic requires a legal basis because existing regulations only regulate in normal conditions. We have to admit that we currently do not have the legal framework at the legal level to hold regional elections in the midst of a disaster. Law Number 10 of 2016 concerning Pilkada only regulates emergencies or disasters in a part of the region. Unlike Covid-19 which was set to be a national disaster, almost all regions that were organizing the 2020 Pilkada were exposed to the corona virus.

The implementation of regional elections in the midst of a pandemic is also not regulated in Law Number 6 of 2020 concerning Pilkada. The Pilkada Law only regulates the postponement and rescheduling of the 2020 Pilkada voting to December from the original schedule in September due to Covid-19. It didn't set the election at all in the midst of a disaster. But because the regional elections continued to be pushed in the midst of pandemic conditions, a legal framework that regulates the technical details of the election, especially its adjustment to health protocols, is needed. If the President does not revoke the disaster emergency situation, then the KPU Decree issued during the Pilkada stage cannot be used as the object of a lawsuit as stated in Article 49 of Law No. 5 of 1986:

- The court is not authorized to examine, decide, and resolve certain State Administrative disputes in the event that the disputed decision is issued:

- in time of war, in a state of danger, a state of natural disaster, or an extraordinary situation that is endangering, based on the prevailing statutory regulations;

- in an urgent situation for the public interest based on the prevailing laws and regulations.

\section{Conclusion}

Based on the description and discussion above, it can be concluded that the legal basis for organizing Pilkada is in the form of Law no. 6 of 2020 does not regulate the implementation of Pilkada during a pandemic, which is regulated only a matter of postponement so that derivative regulations such as PKPU No. 5 of 2020 which regulates Pilkada activities during the Pandemic period has the potential to violate the political rights of citizens, so it can be said that the holding of Pilkada during a pandemic period which does not have a legal basis is invalid according to law.

\section{References}


1. $\quad$ Asshiddiqie, J. (2010). Konstitusi dan Konstitusionalisme Indonesia. Jakarta: Sinar Grafika.

2. $\quad$ Asshiddiqie, J. (2012). Pengantar Ilmu Hukum Tata Negara. Jakarta: Rajawali Press.

3. Arinanto, S.(2000). Constitutional Law and Democratization in Indonesia. Jakarta, Publishing House Faculty of Law University of Indonesia.

4. Kusumaatmadja, M. (2002). Konsep-konsep Hukum Dalam Pembangunan. Bandung, Alumni.

5. Lupu, D., Maha, L. G., \& Viorică, E. D. (2020). COVID-19 Incidence in Europe: Drivers and Government Interventions. Transylvanian Review of Administrative Sciences, 16(SI), 80-93. http://dx.doi.org/10.24193/tras.SI2020.5

6. Raden, S. Pemilihan 2020 di Tengah Pandemik Covid-19, Tantangan dan Harapan Daya Dukungannya, Merdeka.com , 24 April 2020

7. Rohim, N. (2016). Gagasan Pemilukada Serentak dan Implikasinya Terhadap Pesta Demokrasi yang Efektif dan Efisien. Jurnal Nanggroe. Creative Commons Attribution - Non Commercial - No Derivatives 4.0 International License. 